\title{
Promoter Analysis of Public Water Supply Facilities in Southwest Nigeria
}

\author{
${ }^{1 *}$ Iji, J. O, ${ }^{1}$ Bilewu, S. O., ${ }^{2}$ Ajibade, F.O, ${ }^{1}$ Mokuolu, O. A.
}

${ }^{1}$ Department of Water Resources and Environmental Engineering, University of Ilorin, Ilorin, Kwara State, Nigeria .

${ }^{2}$ Department of Civil and Environmental Engineering, Federal University of Technology, Akure, Ondo State, Nigeria

*Corresponding Author E-mail: julianaugama@gmail.com Tel: 08066373328

Submitted on: 11/06/2021

Accepted on: 02/08/2021

\begin{abstract}
Sustainable water supply system is a necessity in growing communities. This study identified Governments, NGO's (Donor and Joint Partnership), and Private Sector (Communities) as the three major promoters of public water supply facilities in a developing country like Nigeria. Secondary data retrieved from the National Water Supply and Sanitation database in the six States of South-West Nigeria was used for the study. The Kruskal-Wallis Test was adopted for the data analysis and description which showed an indication of performance mean rank of promoters. The results indicated that the promoters with highest percentages of operational facilities in the six States are: Communities (ranging between 89\% and 100\%); and NGO's which comprises of both Joint Partnership between two or more promoters and Donor (ranging between $75 \%$ and $100 \%$, and 56\%) respectively. The federal government has the highest percentage of nonoperational facilities in five of the six States ranging between 46\% and 73\%. In the other remaining State (Osun), LGA (Local Government Authority) had the highest percentage of non-operational facilities of $34.1 \%$. There were more operational facilities in $50 \%$ of the States compared to the non-operational. The non-operational facilities are grounded due to broken down machines, poor construction or lack of maintenance and supervision.
\end{abstract}

Keywords: Promoters, Public Water Supply, Operational Facilities, Non-operational Facilities

\section{Introduction}

In developing countries where level of access to water and water related facilities are said to be very low, one of the problems affecting billions of people is lack of access to safe drinking water and basic sanitation (Opafola et al., 2020; Ademiluyi and Odugbesan, 2008). Water is man's most precious resource. Yet it is currently under attack by our waste, pollution, privatization, and the exacerbation of climate change. Man must therefore be aware of this and work to preserve and conserve water for future generations (Adesogan, 2013). Potable water, clean environment and proper hygiene are key factors in ensuring man's survival on planet earth. However, inadequate water supply and lack of basic sanitation have resulted in grave economic and health consequences (Ilori et al., 2019; Odjegba et al., 2015). Poor water supply infrastructure, technical capacity and absence of appropriate regulatory framework are likely reasons for inadequate water supply (Ajibade et al., 2015; Ali, 2012).

Water-supply infrastructure consists of what is built to pump, divert, transport, store, treat, and deliver safe drinking water. Destruction of water supply facilities due to poor management poses the immediate threat of water scarcity which could result to epidemics of waterborne diseases, and several of which can be lifethreatening (Adewumi et al., 2020; Phalkey et al., 2010). These places the greater responsibility of providing safe water to citizens on national Governments, with some input from end users and other stake holders (Omole et al., 2016). Existing water services in many African cities and towns are characterized by intermittent supplies, frequent breakdowns, inefficient operations, poor maintenance, and depleted finance (Cross and Morel, 2005). In Nigeria, the three levels of government (Federal, State and Local) share responsibilities for the delivery of water supply services (Idowu et al., 2012). However, the responsibility for potable public water supply in Nigeria is regarded as social responsibility of the Government and it is traditionally entrusted to the Departments of the State Governments, usually known as State Water Agencies/Corporations (Mokuolu et al., 2015). The performance of water supply works and systems 
operated by State Water Supply Agencies/Corporations is generally unsatisfactory, resulting in inadequate supplies in many cases and necessitates other alternatives. The Federal Government is responsible for formulating and coordinating national water policies and management of water resources (Idowu et al., 2012). The country, though blessed with abundant surface and ground waters still struggles with inadequate water supply; a phenomenon that has led residents across Nigerian cities to rely on water from various sources such as hand dug wells, boreholes, ponds, streams, rivers etc (Odjegba et al., 2015).

A key necessity for improving the lives of urban dwellers is providing access to safe water supply and sanitation (Khandker and Shafiul, 2015). Many governments across Africa have recognized the necessity of structural reforms to break out from the cycle of poor services, lagging collection, weak finances, inadequate maintenance, deteriorating assets, and lagging coverage (Cross and Morel, 2005). In order to meet water supply and sanitation provisions of the reviewed 1977 United Nations declaration that, "all people irrespective of their development, economic and social condition are entitled to have access to drinking water in good quality and quantities", the Federal Government of Nigeria directed and encouraged the establishment of State Water Supply Agency and State Rural Water Supply and Sanitation Agency in each State (Hassan et. al, 2016).

Aside water losses and water shortage in some states in Nigeria, water quality has also been a problem and this can be attributed to inadequate maintenance of infrastructure by the water agency and acts of sabotage by some users, respectively (Omole et al., 2016). Water supply and promoter services delivery to the urban poor is thus a key strategic challenge for African utilities. Effective water resources management is achievable through improved ability of Governmental and non-Governmental organizations; as well as coordinated response at local, national, and international levels (Ufoegbune at al., 2019). The aim of this study is to analyze the promoters of public water supply in Southwestern part of Nigeria with a view to establishing the effectiveness of each promoter in water supply in the study area.

\section{Materials and Methods}

Secondary source of data and a structured questionnaire was adopted in the study. Data was retrieved and collated from the Federal Ministry of Water Resources in Abuja, Nigeria. The Baseline survey was carried out in every Ward in each of the six States of Southwest Nigeria.

\section{Analysis of data}

For the purposes of this study, promoters of public water supply were divided into three groups based on the number or extent of water supply scheme. The group were: Government, Non-Government Organizations (N.G.O.'s) and the Private Sector. Each group was further divided into segments. Thus, Government was divided into three: Federal Government of Nigeria (FGN), State Government and Local Government. Non-Government Organizations (N.G.O.'s) was classified into two: Donor and Joint partnership; and Community was classified as private sector. Additionally, status of water supply facilities was divided into two groups based on their level of operation: those that are operational (OP) and nonoperational (NOP). Statistical analysis was done by adopting Kruskal-Wallis test, which was both descriptive and inferential statistics, in comparing the promoter of public water supply facilities which are in operational and non-operational categories in Southwest Nigeria.

The technique used for the purpose of obtaining information from respondents was a questionnaire. The survey covered Water Supply Facilities which captured the location, attributes, and operational status of these facilities; and the Water Supply Agency Operational Survey was used to collect data on the profile of water agencies in the States, in terms of production assets, capacity utilization, manpower; and financial sustainability. 
LAUTECH Journal of Civil and Environmental Studies

Volume 7, Issue 1; September, 2021

\section{Results and Discussion}

The descriptive analysis and graphical representations of the retrieved and collated data for each State and types of promoter of public water supply are as presented:

\section{Percentage estimation of public water supply facilities promoters in the study area}

Figures 1 to 6 show the distribution of operational and non-operational facilities in the six States studied. Community facilitated facilities constitute $89.7 \%, 75.6 \%$ and $100 \%$ of the functional facilities in three States: Lagos, Oyo and Ekiti, respectively. Also, Joint partnership facilitated highest percentages of operational facilities in 3 States (Ogun, Ekiti and Osun) at 80\%, 100\% and 75\%, respectively while Donor facilitated facilities constitute $56.4 \%$ of the functional facilities in only one State (Ondo). This could imply that the facilities facilitated by Private Sector (Community) and NGO's (Joint partnership and Donor) are properly supervised, constructed and maintained.

In five of the States (Lagos, Ogun, Oyo, Ekiti and Ondo), FGN facilitated facilities constitute 41.8\%, 51.2\%, $45.9 \%, 33 \%$ and $27 \%$ of the non-operational facilities, respectively. This means that FGN has the highest percentage of non-operational facilities in five of the six States under study. This could imply lack of maintenance, inadequate supervision or poor construction of those facilities. In the remaining one State (Osun), Local Governments facilitated $34.1 \%$ of non-operational facilities.

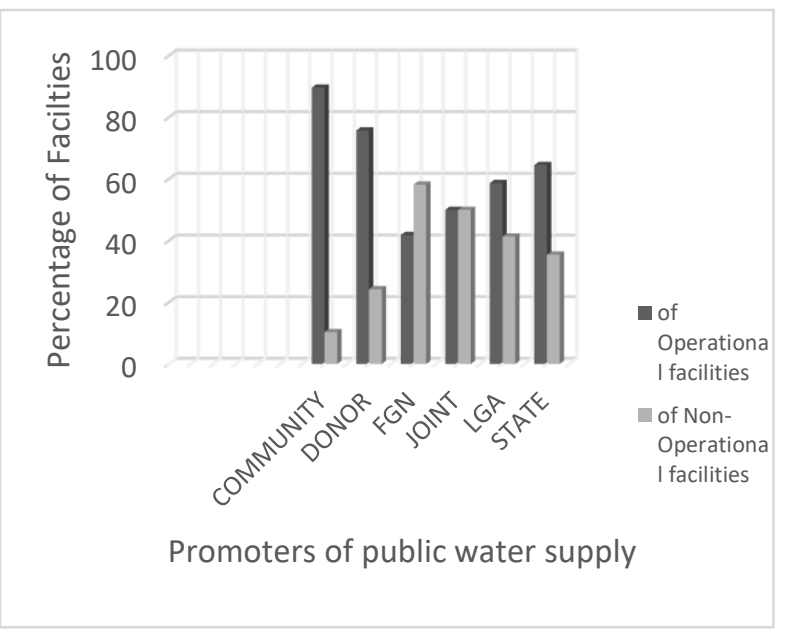

Figure 1: Percentage of water facilities promoted in Lagos

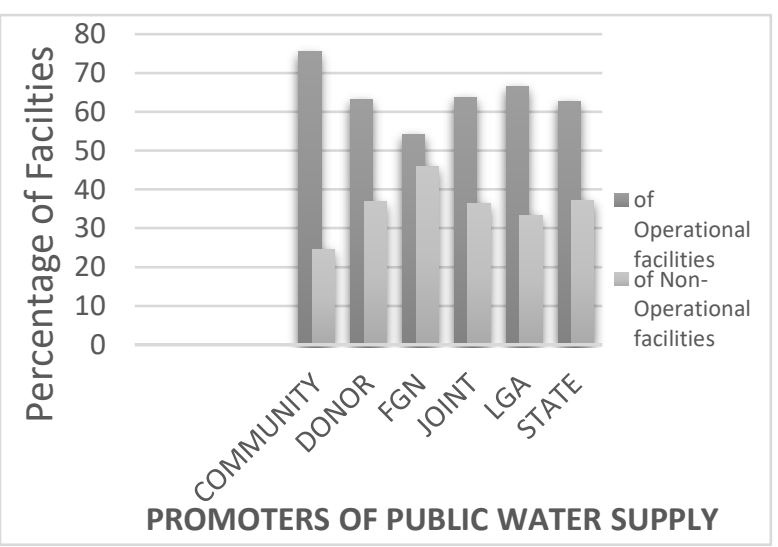

Figure 3: Percentage of water facilities promoted in Oyo State

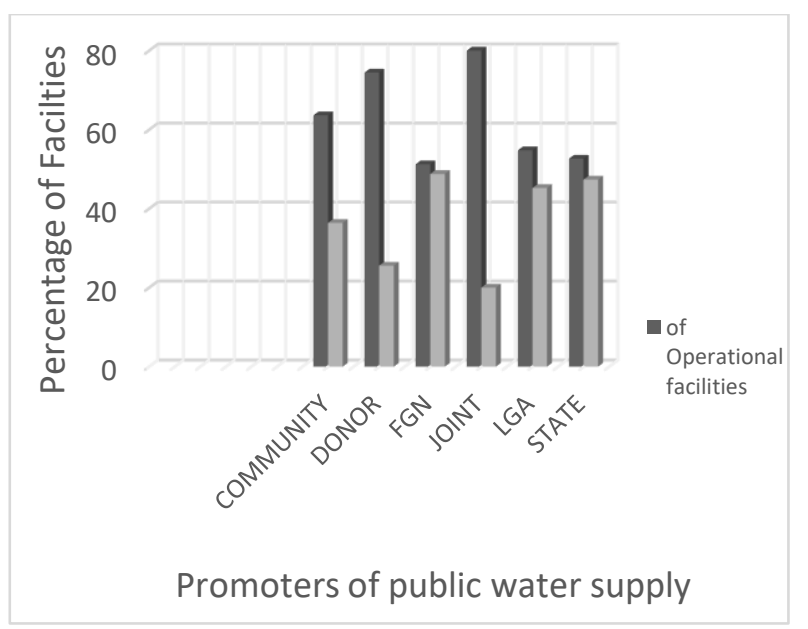

Figure 2: Percentage of facilities promoted in Ogun state

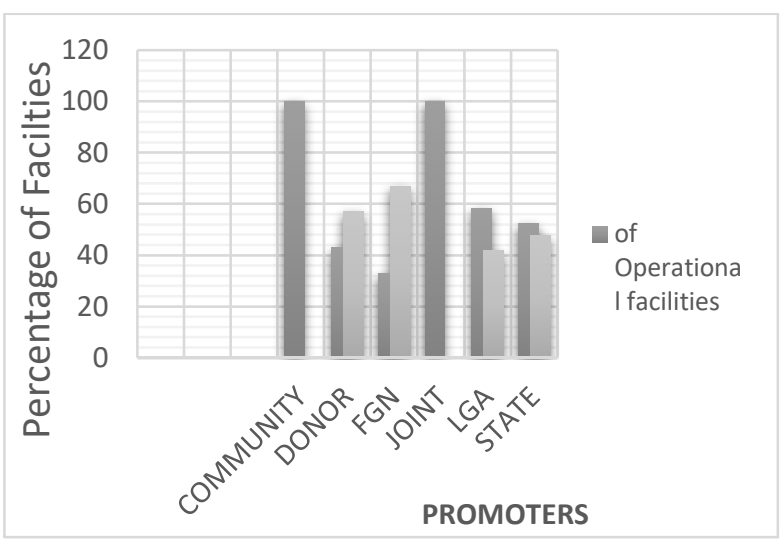

Figure 4: Percentage of facilities promoted in Ekiti State 


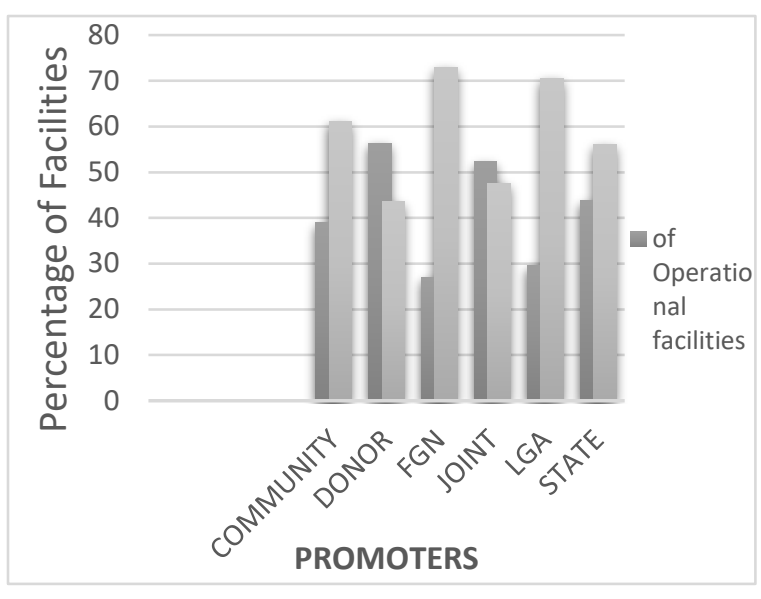

Figure 5: Percentage of water facilities promoted in Ondo State

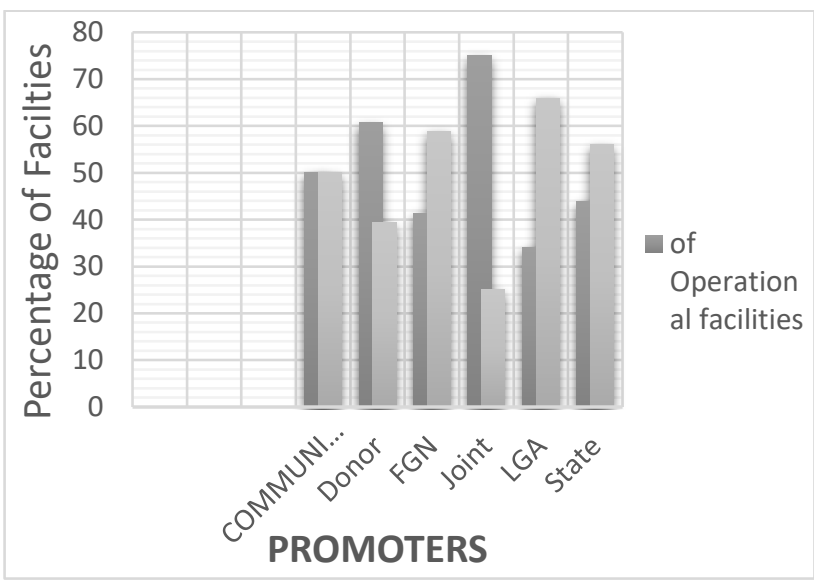

Figure 6: Percentage of facilities promoted in Osun state

\section{Analysis based on operational status of promoters within the South Western States}

Operational and non-operational facilities statistics from respective promoters in each State are presented in Table 1. The means and the medians for each State are calculated from the cumulative frequencies from each promoter for each State. Median statistic is a more reliable measure for cumulative frequencies

Table 1: Operational/Non-operational Status of Water Supply Facilities within the South Western States

\begin{tabular}{lllll}
\hline States & \multicolumn{2}{l}{ Operational facilities } & \multicolumn{2}{l}{ Non-operational facilities } \\
\cline { 2 - 5 } & Mean & Median & Mean & Median \\
Lagos & $74.83 \pm 64.098$ & 60.5 & $47.33 \pm 46.016$ & 44.0 \\
Ogun & $72.17 \pm 55.054$ & 80.5 & $53.67 \pm 49.135$ & 46.5 \\
Oyo & $123.33 \pm 131.357$ & 91.5 & $70.67 \pm 67.917$ & 63.5 \\
Ondo & $63.67 \pm 63.864$ & 32.0 & $86.17 \pm 73.442$ & 72.0 \\
Ekiti & $27.83 \pm 39.321$ & 13.5 & $31.50 \pm 40.362$ & 12.5 \\
Osun & $48.83 \pm 45.937$ & 38.5 & $71.50 \pm 82.779$ & 37.5 \\
\hline
\end{tabular}

It is shown from Table 1 that the operational facilities have higher mean and median values compared to non-operational facilities in five States (Lagos, Ogun, Oyo, Ekiti and Osun). This implies that there are more operational facilities in these five States (Lagos, Ogun, Oyo, Ekiti and Osun) compared to the nonoperational facilities. The functional facilities in these five States are facilitated majorly by private sector (Communities) and NGO's. This could also imply that facilities facilitated by these promoters are adequately constructed, maintained and supervised.

In the other one State (Ondo), the mean and median values of non-operational facilities are higher compared to that of operational facilities. This implies that there are more non-operational facilities in this State (Ondo) compared to the operational facilities. The non-operational facilities in this State are facilitated mainly by the FGN. This could imply that facilities facilitated by FGN are probably poorly constructed, maintained and supervised by this promoter.

Figures 7 to 12 show results presented in boxplots, taking into consideration both the Operational (OP) and Non-operational (NOP) Water Facilities across the six States in South West Nigeria. These boxplots graphically depict the ranked means and median of each water facility promoter across the six States. The mean ranks of the States is an indication of how promoters have fared in the provision of water facilities 
LAUTECH Journal of Civil and Environmental Studies

Volume 7, Issue 1; September, 2021

with respect to operational status. Hence, the higher the mean rank of a State, the higher the impact of the promoter on the State. The size of the boxes is related to the variation in number of facilities promoted by each provider.

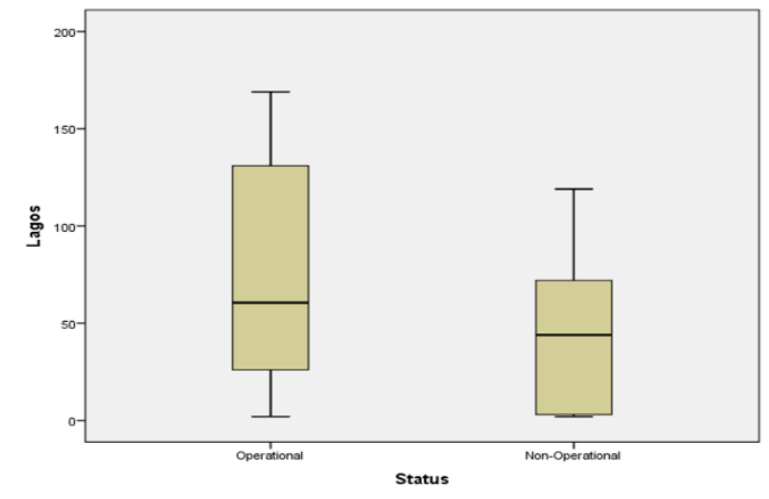

Figure 7: Operational Status of Water Supply Promoters of Lagos State

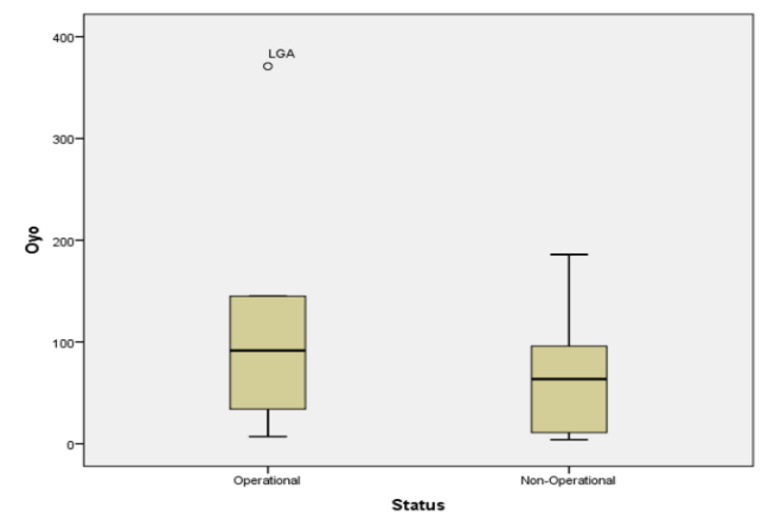

Figure 9: Operational Status of Water Supply Promoters of Oyo State

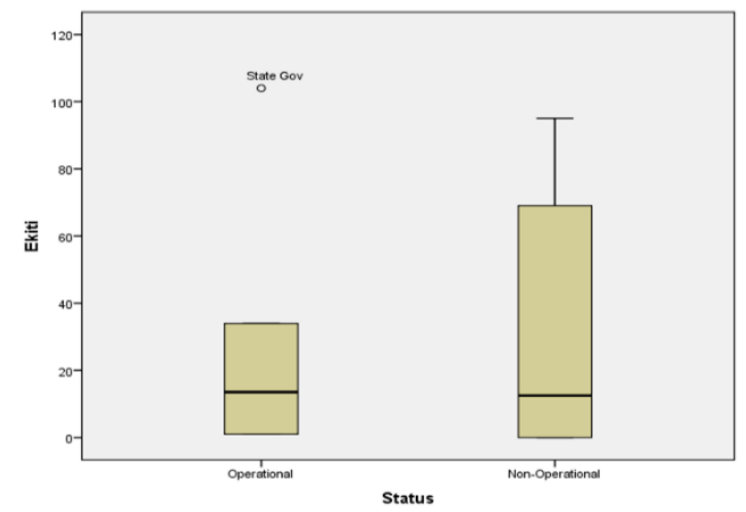

Figure 11: Operational Status of Water Supply Promoters of Ekiti State

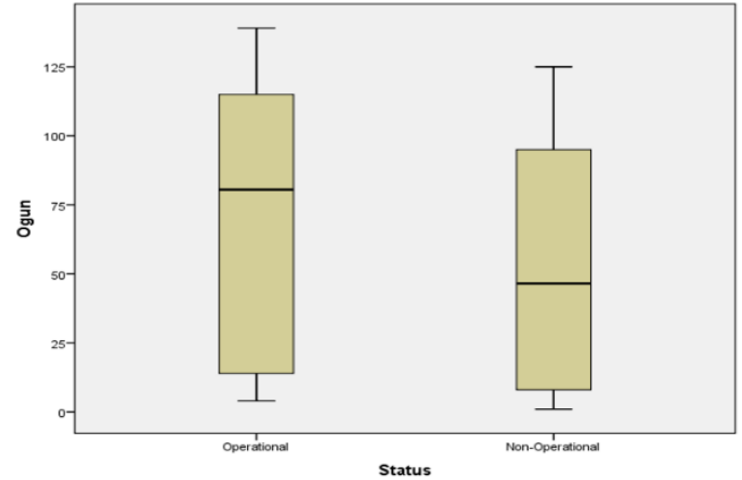

Figure 8: Operational Status of Water Supply Promoters of Ogun State

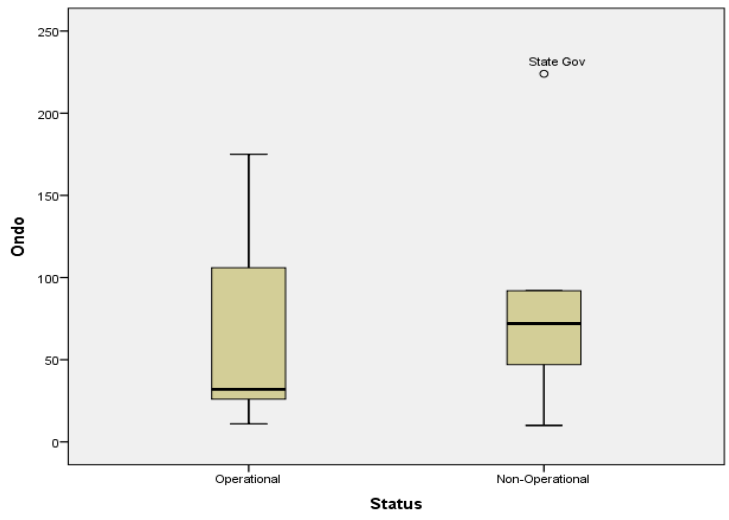

Figure 10: Operational Status of Water Supply Promoters of Ondo State

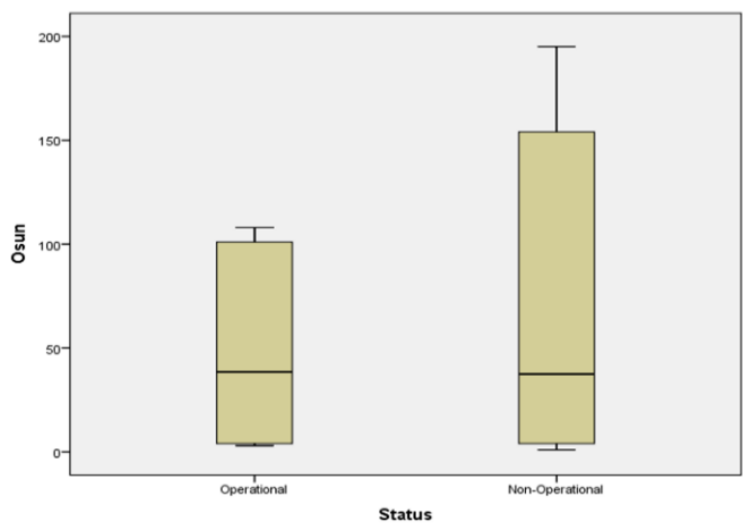

Figure 12: Operational Status of Water Supply Promoters of Osun State 
The Kruskal-Wallis test indicated that differences in Mean Ranks of the Promoters in all the States are significant $(\mathrm{p}<0.05)$. This is shown in Table 2.

Table 2: Kruskal-Wallis Test Showing the differences in Mean Ranks of the Promoters in the States

\begin{tabular}{|c|c|c|c|c|c|c|}
\hline States & Promoter & $\mathrm{N}$ & Mean Rank & Chi-Square & df & Asymp. Sig. \\
\hline \multirow[t]{6}{*}{ Lagos } & Community & 3 & 5.67 & 14.704 & 5 & 0.012 \\
\hline & Donor & 3 & 10.00 & & & \\
\hline & FGN & 3 & 9.00 & & & \\
\hline & Joint & 3 & 2.00 & & & \\
\hline & LGA & 3 & 16.33 & & & \\
\hline & State Gov & 3 & 14.00 & & & \\
\hline \multirow[t]{6}{*}{ Ogun } & Community & 3 & 5.00 & 15.788 & 5 & 0.007 \\
\hline & Donor & 3 & 10.67 & & & \\
\hline & FGN & 3 & 9.00 & & & \\
\hline & Joint & 3 & 2.00 & & & \\
\hline & LGA & 3 & 13.33 & & & \\
\hline & State Gov & 3 & 17.00 & & & \\
\hline \multirow[t]{6}{*}{ Оуо } & Community & 3 & 5.00 & 16.259 & 5 & 0.006 \\
\hline & Donor & 3 & 8.00 & & & \\
\hline & FGN & 3 & 12.00 & & & \\
\hline & Joint & 3 & 2.00 & & & \\
\hline & LGA & 3 & 17.00 & & & \\
\hline & State Gov & 3 & 13.00 & & & \\
\hline \multirow[t]{6}{*}{ Ondo } & Community & 3 & 7.67 & 14.988 & 5 & 0.010 \\
\hline & Donor & 3 & 13.67 & & & \\
\hline & FGN & 3 & 10.00 & & & \\
\hline & Joint & 3 & 2.00 & & & \\
\hline & LGA & 3 & 6.67 & & & \\
\hline & State Gov & 3 & 17.00 & & & \\
\hline \multirow[t]{6}{*}{ Ekiti } & Community & 3 & 3.50 & 16.358 & 5 & 0.006 \\
\hline & Donor & 3 & 8.00 & & & \\
\hline & FGN & 3 & 14.00 & & & \\
\hline & Joint & 3 & 3.50 & & & \\
\hline & LGA & 3 & 11.00 & & & \\
\hline & State Gov & 3 & 17.00 & & & \\
\hline \multirow[t]{6}{*}{ Osun } & Community & 3 & 5.00 & 16.309 & 5 & 0.006 \\
\hline & Donor & 3 & 8.00 & & & \\
\hline & FGN & 3 & 16.00 & & & \\
\hline & Joint & 3 & 2.00 & & & \\
\hline & LGA & 3 & 15.00 & & & \\
\hline & State Gov & 3 & 11.00 & & & \\
\hline
\end{tabular}

The LGA has the greatest impact on Lagos and Oyo States with a mean rank of 16.30 and 17.00 respectively, State Government has the greatest impact on Ogun, Ondo and Ekiti States with a mean rank of 17.0 each. FGN has the greatest impact on Osun State with a mean rank of 16.00. 
LAUTECH Journal of Civil and Environmental Studies

Volume 7, Issue 1; September, 2021

Joint promoter has the least impact on Lagos, Ondo and Osun States with a mean rank of 2.00 each. Joint and Community promoters had least impact of 2.00 and 5.00 respectively on both Ogun and Oyo States, 3.50 each in Ekiti State.

\section{Conclusions}

The major promoters identified in this work are: Government (Federal, State and local government authority), Non-government Organization (Donor and Joint partnership) and private sector (Community participation) water supply scheme. A relationship was established between promoter and water supply facility operational status in Southwestern States (Lagos, Ogun, Osun, Ekiti, Ondo and Oyo) in Nigeria. It showed that Community promoted facilities constitute highest percentages of operational facilities in three states (Lagos, Oyo and Ekiti) while NGO's facilitated highest percentage of operational facilities in 4 States (Ogun, Ekiti, Ondo and Osun). This means that facilities promoted by the private sector and NGO's perform better than Government promoted facilities.

Government promoted water schemes perform badly compared to private and N.G.O promoted schemes in all the six States. This could be due to inadequate supervision, lack of maintenance and or poor construction. It follows therefore that water supply promoters should have a sustainability plan, improve on maintenance culture and have good database for planning project execution.

\section{References}

Ademiluyi, I.A. and Odugbesan, J. A. (2008). Sustainability and impact of community water supply and sanitation programmes in Nigeria: An overview. African Journal of Agricultural Research. Vol. 3(12), Pp 811-817

Adesogan, S. O. (2013). Strategies and Techniques of Providing Adequate and Affordable Potable Water in Rural Areas of Nigeria. International Journal of Water Resources and Environmental Engineering. Vol. 6(1), p. 32-39.

Adewumi, J. R., Ajibade, T.F., Ajibade, F. O. (2020). Appraisal of on-site sanitation facilities and solid waste management in public places within Akure municipality, Nigeria. Journal of Civil Engineering, Science and Technology, 11(1,) $8-21$

Ajibade, F.O., Adewumi, J.R., Ojo, O.M., Babatola, J.O., Oguntuase, A.M., (2015). Issues, Challenges and Management of Water Supply and Sanitation in Nigeria: An Overview. In: Conference Proceedings on National Development Strategies towards Sustainable Civil Infrastructure. In: 13th International Civil Engineering Conference and Annual General Meeting held at Kwara Hotel, Ilorin, Nigeria, 28th - 30th October. Nigerian Institution of Civil Engineers, pp. 19-34.

Ali, K.A. (2012). Development of Water Supply Infrastructure in Nigeria: Challenges and Prospects. Delivered in meeting of the Nigerian Society of Engineers. Available at www.nse.org.ng

Cross, P. and Morel, A. (2005). Pro-poor Strategies for Urban Water Supply and Sanitation Services Delivery in Africa. Water Science \& Technology Vol. 51(8) pp. 51-57

Hassan, A.S., Hayatu, J.M., Mohammed, I.U. (2016). An Overview of Water Supply Infrastructural Challenges in Nigeria: A case study of Taraba State. IOSR Journal of Mechanical and Civil Engineering 13(1) 46-51

Idowu, O.A., Awomeso, J.A., Martins O. (2012). An Evaluation of Demand for and Supply of Potable Water in an Urban Centre of Abeokuta and Environs, Southwestern Nigeria. Water Resources Management 26, Pp 2109-2121

Ilori, B.A., Adewumi, J.R., Lasisi, K.H., Ajibade, F.O. (2019). Qualitative assessment of some available water resources in Efon-alaaye, Nigeria. Journal of Applied Science and Environmental Management Vol. 23 (1), Pp29-34. https://doi.org/10.4314/jasem.v23i1.5.

Khandker Z. H. and Shafiul A. A. (2015). Non-conventional public-private partnerships for water supply to urban slums. Urban Water Journal, 12(7), 570-580, http://dx.doi.org/10.1080/1573062X.2014.923473 
Mokuolu O. A, Sojobi A., Ayanshola, M. A. (2015). Alleviating Water Shortages in University of Ilorin Teaching Hospital, Kwara state, Nigeria. Fulafia Journal of Science and Technology Vol.1:1. 123.

Odjegba, E.E., Idowu, O.A., Ikenweiwe, N.B., Martins, O., Sadeeq, A.Y. (2015). Public Perception of Potable water Supply in Abeokuta South west, Nigeria. Journal of Applied Science and Environmental Management. Vol.19(1) Pp5-9

Omole, D.O, Ndambuki, J.M, Badejo, A.A, Oyewo, D.O and Soyemi, T.O (2016). Public feedback on State of domestic water supply in Lagos: Implications for public health. Indian Journal of Traditional Knowledge Vol.15(2), Pp245-253.

Opafola, O.T., Oladepo, K.T., Ajibade, F.O., David, A.O. (2020). Potability assessment of packaged sachet water sold within a tertiary institution in southwestern. Nigeria, Journal of King Saud UniversityScience, 32(3):1999-2004. https://doi.org/10.1016/j.jksus.2020.02.004

Phalkey R., Runge-Ranzinger S., Guha-Sapir D. and Marx M. (2010). System's impacts of natural Disasters: a systematic literature review. Health for the Millions. 10-25.

Ufoegbune, G.C., Ayodele, D.O., Eruola, A.O., Makinde, A.A., Ojekunle, Z.O., Ilevbaoje, O.O. (2019). Geospatial Design of Optimal Water Distribution Network in Ado-Ekiti, Ekiti State, Nigeria. Journal of Applied Science and Environmental Management Vol.23 (7), Pp 1207-1212. 